\title{
An Economic Analysis of Difficulties in Implementing China's Small Claims Litigation System
}

\author{
Based on Participants' Game Strategy
}

\author{
Haixin $\mathrm{Li}$ \\ Economics School \\ Sichuan University \\ Chengdu, China
}

\begin{abstract}
After the amendment of the China Civil Procedure Law, 2012, the small claims litigation system was originally established and introduced as a system to simplify litigation procedures, improve litigation efficiency, and facilitate people's access to justice. However, in the process of implementation, the system encountered a more obvious "difficult to implement" phenomenon, did not fully play the intended purpose of the system design. Through the discussion and analysis of the theories and methods of law and economics, especially the viewpoints and methods of game theory, it is found that there is a clear conflict between the design objectives of the system of small claims and the interests orientation of the practitioners, which constitutes a strong friction resistance to the implementation of the system. Therefore, in an ideal state, a large number of cases which are applicable to small claims litigation have been "leaked out" through legitimate channels, which to a great extent leads to the "emptiness" of the system. Therefore, we must fully face up to and respect the interest orientation and concern of the subject of the implementation of the system, abandon the unrealistic view of "compulsory application", and take effective dredging of the resistance points of the implementation of the system, strengthening the source of motive force for the implementation of the small claims litigation system, and smoothing the transmission mechanism of motive force as the principle, so as to fully improve the implicit civil litigation system. Only in this way can the mechanism of "price" reach an ideal equilibrium state of behavior and realize its original purpose.
\end{abstract}

Keywords—small claims litigation; judicial reform; game theory; law and economics

\section{INTRODUCTION}

China's small claims litigation system was established when the China's Civil Procedure Law was revised in 2012 and formally implemented in early 2013. Over the past five years, on the whole, the effect of the implementation of the small claims litigation system is very limited, and has not achieved the system designer's intended purpose. How to treat and explain this phenomenon? How to solve this problem fundamentally and effectively? This paper tries to get rid of the research routine of the traditional legal theory, starting from the basic viewpoints and analysis methods of law and economics, and taking the individual behavior of the participants in the system as the micro-foundation of the research and analysis of the system operation, and puts forward its own explanation and countermeasures.

\section{PROBLEMS IN THE IMPLEMENTATION OF SMALL CLAIMS LITIGATION SYSTEM}

Based on the existing published empirical research literature and the author's investigation of some courts in China, there is an obvious phenomenon of "difficult implementation" in the small claims litigation system, which does not meet the expectations of the system designers, including the following three aspects.

\section{A. The Actual Application Rate Is Very Low}

According to the Supreme People's Court of China before the implementation of the system, after the implementation of the system, small claims should account for about $30 \%$ of all civil cases. [1] However, this goal is far from being achieved in terms of published research literature and the author's survey. According to the investigation reports of the courts in Beijing [2], Guangdong[3] and Yueyang, Hunan Province [4], the proportion of the total number of small claim cases concluded by local grass-roots courts to the total number of general summary cases concluded at the same time is very small, usually no more than $3 \%$, and the ratio of the total number of civil cases concluded at the first instance by grass-roots courts at the same time is a few. No more than $2 \%$. From the point of view of the target value, the ratio between the actual trial and the concluding target value in the same period and the civil cases under the upper limit of the applicable standard of the small amount procedure stipulated by law is not more than $10 \%$. In view of this situation, Yan Renqun (2015) even thinks that small claims litigation is in danger of becoming a "virtual procedure"[5].

\section{B. Concentrated Type and to Become Corporate Debt Collectors}

From the empirical research results of Beijing and Guangdong, financial borrowing, property, heating, power, telecommunications enterprises are the main users of the small claims system. It can be seen from this that the small claims 
system can promote people's access to justice, benefit the general public's intended purpose has not been fully realized.

\section{Limited Effect on Improving the Efficiency of Litigation and Reducing Litigation Costs}

The proportion of cases applying small claims procedure in the total number of cases accepted is very small, so the improvement of litigation efficiency of the entire people's court is not very helpful. It is not even as effective as the pilot program launched by the Supreme People's court before 2012. Taking the case study of the grass-roots courts in Beijing as an example, the average trial days of small claims cases in Beijing in 2013, 2014 and 2015 (January to May) are 22, 29 and 35 days respectively, while the average trial days of other summary civil cases in the same period are 38, 42 and 43 days respectively. There is no obvious change between the two. And from the average number of days of trial in all civil cases, 2011, 2012 are 50 days, 2013, 2014, 2015 (January to May) are 51, 58, 56 days[4]. Obviously, after the implementation of the petty lawsuit system, the overall trial efficiency has not been reduced, but has increased. Data from Guangdong courts are similar[5]. Attention should be paid to the fact that, compared with the general summary procedure cases, the cases which apply the small claims procedure are already relatively simple cases, so even if the small claims procedure is not applied, the trial cycle of such cases will not be significantly affected. Therefore, the evidence found in the empirical study can not prove that the small claims litigation system really improves the efficiency of court civil proceedings.

\section{SMALl Claims Ligitigation SYSTEM PARTICIPANTS GAME STRATEGY ANALYSIS}

For the problems in the implementation of the small claims system, empirical research literature has put forward some explanatory measures, but the theoretical depth and explanatory power are obviously deficient. The author holds that the system of petty claims has been in operation for five years. If it is said that it is impossible for judges and litigant participants at the grass-roots level not to understand it and not to use it. From the perspective of economic theory, the participants in the system of small claims can be regarded as complete information. Then the result of the difficulty in the implementation of the small claims litigation system must be the result of the rational choice of the participants in the system. From the basic point of view of game theory, all parties play with each other (or influence each other), and the formation of strategic choice and game results eventually show a relatively stable state. If all participants are not willing to unilaterally change their strategic choices, then this state is the Nash equilibrium state[7]. In this paper, the following abstract around the small claims litigation system of the five participants, one by one analysis of their strategic choices, in order to make a balanced analysis of the game process.

\section{A. The Decision Maker of the High Level Court}

This subject's behavior tendency is to improve the overall working state of the court system, that is, the overall level of justice and efficiency of the case, and to solve the outstanding problems affecting the justice and efficiency of the court as a whole. The strategies adopted by such subjects are: actively promoting the large-scale implementation of the small claims system, tending to exert greater pressure on the grass-roots courts, and calling for vigorous implementation of the small claims system.

\section{B. Judges at the Grass-roots Courts}

If we apply the rational man hypothesis to the judges of the grass-roots court, the behavior orientation of such subjects is usually the minimization of individual risk. This is because, according to the current judicial treatment and remuneration system, the political and economic treatment of judges is rigid in the short term, and will not change significantly in the short term because of the merits and demerits of the case handling performance; and the errors, omissions or petitions of the parties or even extreme behavioral risks will be direct. It brings direct and immediate adverse consequences to the judge himself. The author believes that this assumption is basically consistent with judicial experience. Then, from the point of view of the judges of the grass-roots court, the implementation of the system of small claims brings mainly negative effects, and the benefits of the implementation of the system are secondary, or even negligible. The specific analysis is as follows:

Firstly, due to the characteristics of the compulsory "final trial of first instance" in the current small claims litigation system, the parties will no longer have the opportunity to obtain appeal to change judgment, then the burden of blame of the parties, the responsibility of misjudged cases and the risk of petition, which could be shared by the court of second instance, will be directly borne by the judges at the grass-roots level.

Secondly, if the defendant adopts the delayed litigation strategy, which makes the service procedure difficult and can not reach the trial limit of small claims, the performance evaluation of the judges will be greatly affected. The above two points have been verified in the questionnaires of the judges of the grass-roots courts in Beijing and Guangdong Province.

Thirdly, according to the provisions of the current civil procedure law, the characteristics of the small claims procedure are mainly the "first instance final judgment", and other summary procedures are not obviously different from the general summary procedure in the degree of simplicity. Even after the promulgation of the judicial interpretation of the Supreme People's Court, the relevant operational rules are still unclear, which requires local grass-roots courts to explore on their own. It can be seen that the implementation of the small claims system directly relieves the pressure of appeal cases in the higher courts of the grass-roots courts, but does not directly reduce the pressure of the grass-roots judges. If the judges of grass-roots courts are rational people who tend to minimize individual risks, then the strategy of grassroots judges' possession action is obviously that they do not actively implement the system of small claims and adopt corresponding strategies to evade the application of small claims procedure. 


\section{Grass-roots Court Managers}

There are two specific aspects. On the one hand, these managers and high-level court decision-makers have the same interest orientation, to a certain extent, hope to increase the proportion of small claims (such as performance, performance considerations). But on the other hand, as the above analysis of the behavioral strategies of grass-roots judges, due to the "first instance final judgment" of small-scale litigation, the implementation of the system brought about pressure and conflict risk mitigation of the "welfare" mainly by the higher courts, while the responsibility, risk and pressure of their own courts. Moreover, the pressure risk faced by frontline judges will be directly transmitted by the managers of grassroots courts. Therefore, for such subjects, there are two opposite behavioral strategies. However, weighing the pros and cons of the two, generally speaking, the strategy adopted by such subjects as a whole tends to cooperate with front-line judges to avoid the application of small claims procedure.

\section{Parties to a Case}

Plaintiffs and defendants should be distinguished here. The plaintiff is usually a creditor, so it seems that "first instance final judgment" should be beneficial to the plaintiff. But it should be noted that this conclusion is hypothetical. First of all, the plaintiff must have a high probability of winning the first instance to be inclined to "first instance final judgment"; second, the current Civil Procedure Law has a narrow scope of application for "the final instance of the first instance" in small claims, with the target amount of "the average wage of the employees in the provinces, autonomous regions and municipalities in the last year is less than 30 percent". . From the "cost-benefit" analysis method, it can be easily proved that too low quota cap and too narrow scope of application will make the cost savings and benefits of the second instance litigation brought about by the " first instance final judgment" irrelevant. This will lead to a polarization of the tendency: the higher income people of the litigation brought about by time and economic costs of opportunity to evaluate higher, that claims through the litigation is not reasonable, more inclined to small claims not to prosecute. The low-income people have lower litigation opportunity costs, and more emphasis on the interests of small claims, so they are less sensitive to the cost savings of the second instance litigation, and pay more attention to the second instance relief opportunities. This point has also been confirmed in the empirical study of Beijing. Thirdly, due to the small amount of creditor's rights realized by small claims, only when the litigation costs are fully reduced, the parties can profit by choosing small claims. The way to reduce litigation costs by reducing the litigation cycle is extremely limited, and the real way to reduce litigation costs is to prosecute in batches. Through these three levels of "costbenefit" analysis, we can explain why small claims litigation is actually more used by enterprises to collect debts in batches, while other ordinary people have less application of small claims system. From the point of view of the defendant, it is more advantageous to adopt the formal and legal procedural delay strategy, such as using jurisdictional objections, unaccounted for means to delay trial, obviously unreasonable appeals. Therefore, defendants often have strong motivation to adopt various means to avoid the application of small claims.

\section{E. Other Organs and Public}

According to the questionnaire survey conducted by empirical research in Guangdong Province, the public in a certain range still has doubts about the small claims system, especially the "first instance final judgment". [3]In addition, the attitude towards the organs with supervisory functions of the people's courts (such as procuratorial organs) will also affect the implementation of the small claims litigation system. For example, procuratorial organs have strengthened the study of procuratorial supervision over small claims. Generally speaking, this kind of subject has certain skepticism to the small claims litigation system, and its behavior strategy includes the tendency to exert negative influence on the small claims litigation system.

\section{GAME RESUlts of PARTICIPANTS IN SMALl Claims LIGITIGATION SYSTEM}

After enumerating the above five aspects of the main body and its interest orientation and behavior strategy, we can analyze the "resultant force" formed by the parties around the small claims litigation system, that is, what is the equilibrium state.

\section{A. Perspective of Judges and Managers at the Grass-roots Level}

They are the direct operators and important participants of the system, and their choice of behavior strategy has the most powerful influence on the implementation of the small claims litigation system. According to the current law, the scope of application of small claims proceedings can not be strictly limited in advance, there must be a formally completely legal "leakage" channel. Although this "leakage" channel can be added to a certain limit of management approval. However, with the same analysis, grass-roots court managers are also inclined to cooperate with the application of small claims evasion procedure by front-line judges. It can be predicted that this kind of examination and approval link settings will not have obvious substantive effect. However, it is impossible for the administrators of higher courts to completely block the legal "leakage" channel, which will inevitably lead to a large number of cases suitable for this procedure to circumvent the application of small claims procedure.

\section{B. Perspective of the Parties}

As mentioned earlier, the plaintiff's motive for choosing small claims is very limited, and there is only a very narrow range of motives for choosing small claims. Defendants usually do not have strong will to apply small claims procedures. Although the influence of the litigants on the implementation of the small claims litigation system is relatively indirect, it is indirectly influenced by the game between the grass-roots courts and judges. But the principle of punishment is the basic principle of civil litigation. Although the resistance to the implementation of the petty claims system comes directly from the behavior of the judges in the grassroots courts, the fundamental source of the resistance is still the interest orientation and behavior of the parties. 


\section{Perspective of Other Organs and the General Public.}

Whether other organs or ordinary people, the court, judges at least to a large extent also have a certain degree of distrust. In this case, the worries about the unrestricted trial power brought about by the "first instance final Judgment" are still obvious, which constitutes the unfavorable social consciousness and public opinion atmosphere in the implementation of the small claims litigation system.

\section{Decision Makers of the High Level Court}

As They are not the direct operator of the small claims litigation system, its influence on the implementation of the small claims litigation system is relatively indirect. Therefore, even if the decision-makers of high-level courts have the expectation and will to strengthen the implementation of the small claims system, their role is very limited if they only adopt simplified behavior strategies such as simply ordering, issuing documents and increasing the intensity of assessment.

Under the mutual "game" effect of the above different subjects, the equilibrium result is that the small claims procedure is generally inclined to be avoided and applied only in a limited and economic efficiency principle (such as batch debt collection). Except for the weaker high-level courts, neither side has the incentive to use the system nor the incentive to change its strategic choices. This is the typical Nash equilibrium. This fully explains why the system of small claims is largely "vacant" and why it is so difficult to implement.

\section{COUnTERMEASURES AND SUGGESTIONS}

\section{A. Abandoning the Compulsory Application of "First Instance} Final Judgment" Instead Of "Choosing to Apply"

Because this nominal "compulsory application" can not achieve real "compulsory". From the point of view of the parties, the "compulsory application" to suppress the litigant's rights, ignoring some of the hidden costs. It is better to choose the "first instance final Judgment" on the basis of the unanimous agreement of the parties. This will obviously reduce the "resistance" in implementing the petty lawsuit system.

\section{B. Appropriately Raise the Upper Limit of "Small Amount"}

Too low quota cap and too narrow scope of application of the target will make the welfare of the system of "final trial of first instance" irrelevant, and will not achieve the desired purpose of the system. On the basis of persisting in the application of the parties' unanimous consent, the upper limit of the application of the subject matter of small claims can be raised to twice the average wage of the employed persons in the previous year (about 100,000-150,000 RMB Yuan according to the current statistics in China).

\section{Full Use of "Price Leverage" to Solve Misuse of the Right of Appeal and Other Issues}

The compensation mechanism of litigation expenses should be set up through the incentive of price mechanism, forcing the parties to collect decision-making information before exercising their right of appeal to evaluate the rationality of the appeal behavior, make reasonable appeal decision on their own, and abandon rash appeal behavior.

\section{Careful Assessment of Judges at the Grass-roots Level}

Motivation should be achieved as far as possible by adjusting the interest expectations of the parties, rather than the contrary - encouraging grass-roots courts and judges to drive and influence the parties' behavior in their own interest orientation. It is not appropriate to use the indicators such as "the applicable rate of small claims" to assess grass-roots courts and judges [8]

As a conclusion, we would like to emphasize that the current situation of the implementation of the small claims litigation system is difficult. The deep reason lies in the lack of cost thinking and game theory thinking. In order to improve the efficiency of civil litigation and achieve the goal of simplified diversion, the fundamental method is still sufficient to make full use of the "price" mechanism implied in the supporting system, guide the parties to make rational choices according to their own interests, reasonable choice of litigation procedures.

\section{REFERENCES}

[1] Xie Yong: Du Wanhua, Member of the Judicial Committee of the Supreme People's Court of China, stressed the importance of making preparations for the implementation of small claims litigation in Ningxia in 2012, People's Court Daily, October 9, 2012, 1st Edition.

[2] Liao Wanchun et al. Perfecting the System of Small Claims and Standardizing the Ways of Procedural Relief: A Report of Guangdong High Court on the Implementation of the System of Small Claims, People's Court Daily, May 8, 2014,the 8th Edition.

[3] Lu Junfang, Niu Jiawen and Xiong Wangxian: The Predicament and Outlet of the Operation of China's Small Claims Litigation System: Based on the Trial Practice of Beijing Grass-roots Court, Law Application, No. 3, 2016.

[4] Zhan Shangang and Shi Yao: An Empirical Study on the System of Small Claim Litigation - Taking Some Grass-roots Courts in Yueyang City as the Research Object, Journal of Henan University of Finance, Economics and Law, No. 3, 2016.

[5] Yan Renqun: Reflections on the Difficulties of Transplanting Small Claims Procedure, Journal of Jiangsu Administrative College, No. 3, 2015 .

[6] Wang Yefeng, The Difficulties and Countermeasures of Procuratoria Supervision in Small Claims Procedure, China Public Prosecutor, No. 7 , 2016.

[7] Douglas G. Baird, Robert H. Gertner and Randal C. Picker, Game Theory and the Law, Harvard University Press, 1998, pp:17-18

[8] Li Yongjun and Fu Aizhu: Justice of "Discipline" and "Restrained" Judges: A Deep Interpretation of the Difficulties and Misunderstandings of Judge Performance Appraisal System, Journal of Northwest University of Political Science and Law, No. 6, 2014 